\title{
Increased ghrelin sensitivity and calorie consumption in subordinate monkeys is affected by short-term astressin B administration
}

\author{
Vasiliki Michopoulos ${ }^{1}$, Tammy Loucks ${ }^{2}$, Sarah L. Berga ${ }^{2}$, Jean Rivier ${ }^{3}$, and Mark E. \\ Wilson $^{1}$ \\ ${ }^{1}$ Division of Psychobiology, Yerkes National Primate Research Center, Emory University, Atlanta \\ GA 30322 \\ ${ }^{2}$ Department of Gynecology \& Obstetrics, Emory University School of Medicine, Atlanta GA \\ 30322 \\ ${ }^{3}$ The Clayton Foundation Laboratories for Peptide Biology, The Salk Institute, La Jolla, CA 92037
}

\begin{abstract}
Animals chronically exposed to stressors with access to diets high in fat and sugar consume and prefer these diets, a result consistent with the association between stress and comfort food ingestion in humans. As social subordination in rhesus monkeys provides an ethologically relevant translational model of psychosocial stress, we tested the hypothesis that differences in food intake between dominant and subordinate female monkeys are due to corticotropin-releasing hormone $(\mathrm{CRH})$ induced alteration in sensitivity to ghrelin, a potent orexigenic signal. We assessed food intake of animals given a choice between a low (LCD) and high calorie diet (HCD) in response to four-day treatment with the $\mathrm{CRH}$ receptor antagonist, astressin $\mathrm{B}$, and to an acute treatment of ghrelin. Ghrelin stimulated intake of LCD in subordinates but did not further increase consumption of HCD, whereas ghrelin decreased LCD consumption without affecting HCD intake in dominant females. Astressin B decreased cortisol levels and increased preference for and intake of the HCD in subordinates and decreased calorie intake and HCD preference in dominant animals. These results suggest that increased caloric intake by subordinates may, in part, be explained by a greater sensitivity to postprandial increases in ghrelin and that $\mathrm{CRH}$ receptor antagonism leading to a decrease in cortisol has mixed effects on food choice depending on an individual's stress background.
\end{abstract}

\section{Keywords}

ghrelin; CRH receptor; food intake; diet preference; behavior; astressin B

\section{Introduction}

\begin{abstract}
Exposure to acute and chronic stressors plays a central role in energy balance by altering food intake [1]. Rodents and non-human primates exposed to chronic stressors show a reduction in body weight when fed a standard low fat, high fiber diet [1-5]. However, when given access to diets high in fat and sugar, chronically stressed rodents eat greater amounts of these diets in comparison to low calorie diets [6,7], allowing for a preference for this high
\end{abstract}

Send correspondence to: Vasiliki Michopoulos, Yerkes National Primate Research Center, Emory University, 954 Gatewood Road, Atlanta GA 30329, 404-712-9420, 404-727-8088 (fax), vmichop@emory.edu. 
fat high sugar diet to emerge. The preference for high calorie diets during extended exposure to stressors is consistent with the association between stress and comfort food ingestion in humans $[8,9]$.

Corticotropin-releasing hormone ( $\mathrm{CRH})$, the central mediator of the limbic-hypothalamicpituitary-adrenal (LHPA) axis, likely affects food intake $[1,10]$ and, through its stimulation of glucocorticoids, increases preference and intake of high calorie diets (HCD) containing sugars and fats [11]. Furthermore, CRH acts directly in the paraventricular nucleus of the hypothalamus and in the arcuate nucleus of the hypothalamus to modulate food intake [12] via its two receptors, $\mathrm{CRH}$ receptor type 1 (CRHR1) and CRH receptor type 2 (CRHR2) $[1,10]$. Even though the specific mechanism mediating CRH's effects on food intake remains unclear, CRH has the ability to disrupt feeding at the level of the arcuate nucleus of the hypothalamus, as CRH activity modulates expression of the orexigenic signals neuropeptide Y (NPY) and agouti-related protein (AgRP) [13,14]. Furthermore, CRH and cortisol activity is capable of altering sensitivity to peripheral metabolic signals, such as leptin [15]. Another peripheral signal whose actions have been suggested to be altered under conditions of chronic stress is ghrelin [16], an orexigenic peptide secreted from the stomach. Heightened CRH and LHPA activity characteristic of chronic stress exposure could alter the potency of ghrelin via growth hormone secretagogue receptors in the arcuate nucleus and caudal brainstem to stimulate food intake $[17,18]$.

While studies that examine the interaction between chronic exposure to stressors and food intake are difficult to perform in humans, socially housed female rhesus monkeys provide an ethologically relevant translational model of psychosocial stress. Female monkeys, like human beings, live in a stratified society wherein subordinate animals experience adverse consequences due to their social status [19,20], including hypercortisolemic due to reduced glucocorticoid negative feedback [21-23]. Furthermore, subordinate females show decreased body weight and circulating leptin levels when maintained on a standard monkey diet in comparison to dominant animals [3]. Interestingly, ghrelin concentrations are not lower in subordinate female rhesus monkeys [3], suggesting differences in food intake during subordination stress might be explained by differential sensitivity to ghrelin. However, when given access to diets that are high in sugar and or fat, subordinate females consume significantly more calories per day than do dominant females [23]. The mechanisms responsible for this status difference in intake of high caloric foods are not known.

The objective of the current study was to define the relation between psychosocial stress exposure (social subordination), ghrelin sensitivity, and food intake and preference in female rhesus monkeys. We tested the hypothesis that differences in food intake between dominant and subordinate female monkeys are due to alteration in ghrelin sensitivity. Furthermore, we determined whether treatment with the CRH type 1/2 receptor antagonist peptide astressin $\mathrm{B}$, would alter CRH-induced changes in ghrelin sensitivity and decrease preference and intake of a HCD in subordinate females to levels comparable to those seen in dominant animals. Finally, because the psychosocial stress of subordination is imposed through harassment or non-contact aggression by more dominant animals, we also evaluated differences in social behaviors in response to astressin B.

\section{Methods}

\section{Animals}

Previously ovariectomized adult female rhesus monkeys $(n=9)$ living in indoor-outdoor enclosures (in groups of 4 and 5) were used as subjects as previously described [23]. Animals had access to experimental diets ad libitum via automated feeders to allow for quantification of individual caloric intake [23]. Briefly, each animal was implanted with a 
radio-frequency identification chip in each wrist. An antenna read these chips and signaled a computer to dispense a single pellet of food via an automated pellet dispenser. This event was recorded in a $\log$ on a computer, allowing for the constitutive monitoring of individual animal food intake. A feeder is only activated and dispenses a pellet if the animal's hand breaks the plane of the antenna surrounding the food cup. Under these conditions, pellets were never discarded and dominant females rarely $(<1 \%)$ took the pellet from a subordinate animal. Thus, the system accurately records food intake and diet preference in socially housed monkeys [23]. Subjects had a choice between a low calorie monkey chow (LCD; $3.61 \mathrm{kcal} / \mathrm{g}$, Purina 5038) and a high calorie diet (HCD; $5.54 \mathrm{kcal} / \mathrm{g}$ Research Diets of America). The caloric breakdown of the LCD was $12 \%$ fat, $18 \%$ protein, and $4.14 \%$ sugar carbohydrate and $65.9 \%$ fiber carbohydrate. The calories of the HCD were distributed as $40 \%$ fat, $20 \%$ protein, $14.8 \%$ sugar carbohydrate and $25.2 \%$ fiber-starch carbohydrate.

Rhesus monkeys provide an ethologically valid, translational model in which to study adverse health effects that are comorbid with psychosocial stress. Lower ranking animals receive proportionately more aggression from higher-ranking group mates and these subordinates terminate these interactions by emitting submissive behavior [19]. Given the recurrent exposure to harassment from more dominant females, subordinate females have larger adrenal glands [21] and show a greater cortisol response to social challenges [24]. In addition, pharmacological tests using a dexamethasone suppression [3,25-29] or ACTH challenge [29] show subordinate females are hypercortisolemic. The use of social subordination in macaques is a well established model to study the adverse effects of psychosocial stress on cardiovascular disease [30], addictive behavior [31], central monoamine changes [29,32,33], reproductive compromise [30,34], alterations in immune function [27,35], and an increase in anxiety-like or displacement behaviors [25,36] known to be stress dependent [37]. Group dominance ranks were determined based on the outcome of dyadic interactions between females where a female clearly elicited a submissive response to another animal [19]. Females ranked one and two were classified as dominant $(n=4)$ and females ranked 3-5 were considered as subordinate $(n=5)$ [21]. Groups had been formed and dominance ranks stable for 96 months prior to the initiation of this study. The Emory University Institutional Animal Care and Use Committee approved all procedures in accordance with the Animal Welfare Act and the U.S. Department of Health and Human Services "Guide for Care and Use of Laboratory Animals."

\section{Study design}

Females were studied for two one-week treatment phases separated by a two-week washout period. Each phase consisted of either a four-day saline treatment, designated hereafter as the control condition, or a four-day treatment with the mixed CRH type 1/2 receptor peptide antagonist, astressin B [38]. Astressin B was chosen as it reduces cortisol secretion in monkeys when administered peripherally [39]. The dose of astressin B used $(0.45 \mathrm{mg} / \mathrm{kg} /$ day in saline) was based on studies assessing effects of LHPA activation on luteinizing hormone secretion in monkeys [39]. For the control condition females received SC injections at approximately $0800 \mathrm{hr}$ on each of four consecutive days. The treatments (control versus astressin B) were counterbalanced across the nine females between the two four-day phases.

On the morning of day three of both the control and astressin B treatment conditions, females received either saline ( $0.25 \mathrm{ml}, \mathrm{IV})$ or ghrelin (100 $\mu \mathrm{g} / \mathrm{kg}$ in saline, IV; [39]) coincident with the astressin B or control. On the morning of day four, females received the other treatment. The order of ghrelin versus saline on these two days was counterbalanced across females. A blood sample was obtained prior to each injection for plasma ghrelin and serum cortisol determination. A one-hr behavioral observation was conducted beginning 30 minutes after the injection time using the standard rhesus monkey ethogram, including 
affiliative, aggressive, and submissive behaviors. Data were recorded using a Palm PDA and the "Hands Obs" program developed by the Center for Behavioral Neuroscience [40]. Interobserver reliability exceeded $90 \%$. Thirty minutes following the end of the behavioral observation, a second blood sample (two hours following injection) was collected to assess ghrelin and cortisol levels. We compared food intake in the four-hour period following the ghrelin injection to the same period following the saline injection to assess status-related differences in food intake.

\section{Sampling and assay methods}

All subjects were habituated to being removed from their group for conscious venipuncture using previously described procedures [41] in place in the lab for over 30 years. Blood samples were obtained within 10 minutes from entering the animal area to minimize arousal [42]. Serum levels of cortisol were measured by radioimmunoassay with a commercially available kit (Beckman-Coulter/DSL, Webster TX). Using $25 \mu$, the assay has a range from 0.5 to $60 \mu \mathrm{g} / \mathrm{dl}$ with an inter- and intra-assay CV of $4.9 \%$ and $8.7 \%$, respectively. Acylated ghrelin levels were determined by ELISA following sequential addition of aprotinin and $1 \mathrm{M}$ $\mathrm{HCl}$ to the sample as to minimize ghrelin degradation (ALPCO, Boston MA). The assay has a range from 1.96 to $250 \mathrm{pg} / \mathrm{ml}$ with an inter- and intra-assay CV of $4.47 \%$ and $5.50 \%$, respectively. All assays were done at the Yerkes National Primate Research Center (YNPRC) Biomarkers Core Lab.

\section{Statistical analyses}

Data were summarized as mean \pm standard error of the mean (SEM). The main and interaction effects of status (dominant vs. subordinate), antagonist treatment (control vs. astressin B), ghrelin challenge (saline vs. ghrelin) on consumption of the LCD versus the HCD, over time was evaluated with analysis of variance for repeated measures (RMANOVA). Feeding data following ghrelin or saline injections were analyzed using feeding two-hours prior to injection time as a covariate to control for the amount of food a female ingested prior to the assessment as some females had fed during these hours. Test results with a $\mathrm{p} \leq 0.05$ were considered significant.

\section{Results}

\section{Effects of astressin B on cortisol concentrations}

There was a significant interaction between astressin $\mathrm{B}$ treatment and time on treatment for morning cortisol levels $\left(\mathrm{F}_{1,7}=6.92, \mathrm{p}=0.03\right.$; Figure 1$)$. Treatment with astressin $\mathrm{B}$ decreased basal cortisol levels on the morning of day four in all animals regardless of status compared to both day three and four of the control treatment phase and day three of astressin B levels (Figure 1).

\section{Assessment of sensitivity to ghrelin}

Not surprisingly, acute ghrelin administration significantly elevated circulating ghrelin levels compared to the saline treatment condition $\left(91.58 \pm 18.12\right.$ vs. $25.76 \pm 11.14 \mathrm{pg} / \mathrm{ml} ; \mathrm{F}_{1,7}$ $=22.4, \mathrm{p}=0.002)$. Furthermore, ghrelin administration did not affect cortisol levels $(\mathrm{p}>$ 0.05 ), as the change in cortisol two hours following ghrelin and saline administration was not significantly different after injection $(32.9 \pm 2.50 \mathrm{vs} .31 .7 \pm 2.15 \mu \mathrm{g} / \mathrm{dl})$. Finally, there was no main or interaction effect of astressin B or social status on circulating concentrations of ghrelin following injection $(\mathrm{p}>0.05)$.

Because females were not fasted before administration of ghrelin or saline, total calorie intake during the two hours immediately before these injections at $0800 \mathrm{hr}$ was used as a covariate in the analysis of ghrelin effects on feeding. There was no significant overall main 
effect of status, diet, astressin B, ghrelin $\left(\mathrm{F}_{1,3}=0.01, \mathrm{p}>0.05\right)$ or an interaction between social status and diet $(p>0.05)$. Because the effect of order of ghrelin versus saline injection on days three and four of each phase was not significant $\left(\mathrm{F}_{1,3}=0.38, \mathrm{p}>0.05\right)$, treatment order was not considered in the analysis. Treatment with astressin B did not modify the effects of ghrelin on food intake over the four-hour period in dominant and subordinate females $\left(F_{1,7}=0.032, p>0.05\right)$; consequently, the effects of these treatments are presented separately for clarity. As illustrated in Figure 2, ghrelin treatment interacted significantly with status to affect diet preference and calories consumed $\left(\mathrm{F}_{1,7}=7.01, \mathrm{p}=0.05\right)$, but not with hours from ghrelin injection ( $P>0.05$, Table 1$)$. Consumption of the LCD was significantly decreased by ghrelin in dominant animals but increased in subordinate females ( $\mathrm{p}<0.05)$. Thus, while LCD consumption was similar between dominant and subordinates females during saline, subordinates ate more LCD following ghrelin than did dominant females. In contrast, consumption of the HCD was not statistically different following saline or ghrelin in either dominant or subordinate females.

As shown in Figure 3, administration of astressin B also interacted with status to significantly influence diet preference and food intake $\left(\mathrm{F}_{1,7}=14.2, \mathrm{p}=0.01\right)$. For dominant females, astressin B decreased consumption of both the HCD and LCD compared to the control condition $(p<0.05)$. In contrast, administration of astressin $B$ increased consumption of the HCD $(\mathrm{p}<0.05)$ but did not affect consumption of the LCD in subordinate females $(\mathrm{p}>0.05)$. Consequently caloric consumption was significantly increased by astressin B in subordinate animals $(\mathrm{p}<0.05)$.

\section{Treatment effects on behavior}

Figure 4 shows the changes in behavior following saline and ghrelin administration during both the control and astressin B conditions. A main effect of status $\left(F_{1,7}=14.4, p<0.01\right)$ on total aggressive behavior was present, as dominant animals displayed significantly more aggressive behaviors towards subordinate females (Figure 4A). This constant harassment by dominant animals was associated with correspondingly higher rates of submissive behaviors by subordinate females (Figure 4B; F 1,7 $=14.7, \mathrm{p}<0.01$ ). There was no effect of ghrelin or astressin $\mathrm{B}$ on submissive and aggressive behaviors, and there were no significant interactions between status, ghrelin, and astressin B ( $p>0.05)$.

Figure $4 \mathrm{C}$ shows that dominant females displayed significantly higher rates of affiliative behavior than did subordinate animals $\left(\mathrm{F}_{1,7}=7.68, \mathrm{p}=0.03\right)$. Moreover, astressin $\mathrm{B}$ administration significantly increased affiliation $\left(\mathrm{F}_{1,7}=7.02, \mathrm{p}=0.03\right)$, in a status dependent manner $\left(\mathrm{F}_{1,7}=5.44, \mathrm{p}=0.05\right)$, as dominant animals directed significantly more affiliative behavior towards group mates following astressin B administration whereas subordinate females did not. There was no effect of ghrelin on affiliation and no significant interactions between ghrelin, status and astressin B on affiliative behaviors ( $p>0.05)$.

\section{Discussion}

Exposure to stressors in animal models suppresses feeding and leads to a decrease in food intake when a low calorie diet is available $[1,3,43,44]$. This decreased food intake has been linked to the activity of LHPA axis, specifically the anorexic actions of CRH, as this peptide hormone acts at the level of the hypothalamus, caudal brainstem, and central nucleus of the amygdala $[18,45,46]$ to regulate food intake via its two receptors, CRHR1 and CRHR2 $[1,10]$. However, an increasing number of studies now suggest that when given access to diets high in fat and/or sugar, rodents and monkeys exposed to chronic stressors prefer these high calorie foods and consume more calories than do non-stressed controls [7,9,23,47], an effect due to the central actions of glucocorticoids and insulin affecting food salience [11]. 
Because we have previously shown that plasma ghrelin levels do not differ between dominant and subordinate females [3], the present study tested the hypothesis that the increased consumption of a HCD by subordinate females would be explained by a greater sensitivity to ghrelin. Although the half-life of ghrelin in humans following a bolus administration is between 10 and 31 minutes [48-50], its actions on food intake are rapid [51]. Ghrelin in rodents acts at the level of the arcuate nucleus of the hypothalamus to initiate food intake via the orexigenic neuropeptides NPY and AgRP within one hour following its administration [52,53]. Additionally, central ghrelin administration in rats increases fat ingestion two hours after ghrelin injection [54,55]. In our study, food intake was monitored for four hours following ghrelin injection due to this described rapid onset of ghrelin's action to initiate feeding. Ghrelin increased consumption of the LCD in subordinates whereas intake of the LCD was decreased with ghrelin in dominant animals compared to the saline treatment. These data suggest that subordinate but not dominant animals are sensitive to the orexigenic action of ghrelin for a LCD, even in a fed state. However, the data also indicate all animals are insensitive to ghrelin in increasing further consumption of a diet high in sugar and fat. It is possible that the dose of ghrelin used in this study was not capable of further stimulating HCD consumption by subordinates above already high intake levels. Alternatively, the lack of an effect of ghrelin on HCD consumption suggests that the overall preference for the HCD in all animals is driven by a mechanism independent of ghrelin and its direct actions on ingestive neural networks. This overall status-independent effect on HCD consumption during the ghrelin assessment suggests that the acquisition and reinforcement of HCD feeding is similar in both groups of animals, possibly acting through the mesolimbic dopamine system [56].

Previous data has shown that ghrelin increases glucocorticoid secretion, presumably acting via NPY and AgRP to stimulate the LHPA axis $[57,58]$. In our study, we did not see an increase in cortisol levels two hours following IV ghrelin administration. The lack of an effect on cortisol release might be due to differences in the administration protocol, as we injected a bolus while the continuous infusion of ghrelin over five hours in rhesus macaques increases cortisol levels 45 and 90 minutes following initiation of ghrelin administration [39].

To determine whether $\mathrm{CRH}$ receptor activity is necessary for these subordination-induced differences in feeding behavior, we utilized the mixed CRHR1/2 peptide antagonist astressin B [38]. We found daily subcutaneous administration of astressin B over four days was physiologically efficacious as it decreased morning cortisol levels in all subjects, regardless of social status, an effect most likely due to antagonism of pituitary CRH receptors leading to the attenuation of adrenal cortisol secretion [39]. Even though this finding corroborates previous data describing astressin B's ability to reduce cortisol levels in monkeys [38,39], the administration of astressin B had a delayed response in the treatment paradigm employed in the current study since there was a cumulative effect of the antagonist on cortisol, as the decrease in cortisol levels was not seen until the fourth day of treatment. Discrepancies between the current study and these other studies could be accounted by the different administration protocols, as the previous studies used provocative agents concurrently with astressin B such as CRH to assess its ability in blocking LHPA activation [38]. Our data are the first to administer astressin $\mathrm{B}$ in a chronic manner and suggest that the agent might require more time to dampen LHPA activity when there is a constant threat to homeostasis (subordination) and not a concurrent provocative challenge.

The lack of a social status effect in the morning cortisol in response to astressin B is not surprising the analysis of a single morning sample for cortisol may provide limited power to detect these group differences and consequently be a poor surrogate measure of social status differences in LHPA $[59,60]$. As subordination-induced dysregulation of the LHPA is best 
characterized by provocative tests $[21,23,28]$, the use of a single sample to show status differences in cortisol yields variable results [59-61]. Indeed, the use of a dexamethasone suppression test reveals that subordinate females are hypercortisolemic due to diminished negative feedback of the LHPA axis [22,23,62]. Importantly, the higher rates of aggression or harassment directed towards subordinates provides evidence that social subordination is a stressor in macaque groups [20] and administration of astressin B did not influence these behaviors.

Astressin B administration modulated food intake differentially in dominant and subordinate animals regardless of ghrelin treatment, as astressin B decreased overall calorie intake and HCD preference in dominant animals and increased the preference and intake of HCD in subordinate animals. Critically, there was no main effect of status on total calorie intake over the four hours of the ghrelin challenge and no status by diet interaction indicating that subordinate and dominant animals ate similar amounts of both diets overall within this experimental design. The lack of this overall difference in intake suggests that the specific context and experimental paradigm employed in this study were not sufficient to observe the overall status difference in total calorie intake and diet preference that we have seen previously in socially housed female monkeys [23]. Specifically, in the current study, only four hours of food intake in the morning were assessed and status differences in food intake emerge over the course of an entire 24-hour period as subordinate animals eat more during the nighttime than dominant animals [23]. Regardless of the lack of a status difference in overall intake and diet preference, the feeding data from subordinates on astressin B and dominant animals during the control condition were similar even though the total number of calories consumed by subordinates was unaffected by astressin B treatment. Assessing food intake and responsivity to ghrelin after a longer treatment with astressin B may have produced a different pattern of food intake in subordinate animals, such that calories consumed would have been lower and the preference for the HCD diminished. Because glucocorticoids shift diet preferences to calorically dense foods [11], it seems unlikely that the pattern of food intake in subordinates given a choice between a HCD and LCD occurs independent of LHPA involvement.

The administration of the astressin B did not alter dominance rankings within the groups, as agonistic behavior was unaffected by peripheral CRH receptor antagonism. Interestingly, daily administration of astressin B increased affiliative behavior directed at group mates by dominant females. This change in the motivation to engage in affiliation in dominant animals during astressin B treatment is consistent with other data showing an interaction between glucocorticoid levels and affiliative behavior, as increases in affiliation and social support result in decreased glucocorticoids levels (for review see [63]). In addition, increases in affiliation in monkeys [64,65] and humans [66] are associated with decreases in cortisol levels. The finding that affiliative behavior did not increase but cortisol levels decreased in subordinate females, however, suggests that other factors are involved. Alterations in the serotonergic system characteristic of chronic exposure to stressors [33] might also account for the status difference in affiliative behavior seen in subordinate animals, as serotonin also facilitates affiliation $[67,68]$. The possibility remains that changes in CRHR receptor expression associated with chronic stress [69] in regions involved in prosocial behaviors, such as the amygdala [70], are altered in subordinate monkeys in a manner that renders them unable to respond behaviorally to decreased cortisol levels.

In conclusion, the data indicate subordinate females indeed have increased sensitivity to ghrelin that promotes consumption of a LCD. Interestingly, ghrelin sensitivity towards consumption of the HCD was unaltered in both dominant and subordinate animals, suggesting that mesolimbic reward circuits [56] might be driving the increased preference for this diet in both groups of animals. Additionally, the administration of the nonspecific 
CRH receptor peptide antagonist astressin B further increased intake of a HCD [23], thus failing to elicit a change in sensitivity to ghrelin similar to that seen in dominant females. These data suggest that even though the cumulative effect of a CRH antagonist might provide relief from the hypercortisolism and behavioral disruptions characteristic of chronic stress disorders such as depression [71], a more chronic treatment with such a pharmacological intervention might be necessary to affect stress-induced disruptions in ghrelin sensitivity and food intake. These and other findings that implicate ghrelin in stressinduced neuroendocrine alterations in reproductive function [39] emphasize the importance of studying multiple facets of one molecule's actions, as understanding how multiple systems interact might provide insight regarding the etiology stress-induced deficits in behavior, appetite, and reproductive competence observed in humans, such as women with functional hypothalamic amenorrhea [72].

\section{Acknowledgments}

The study was conducted with the invaluable technical assistance of Jennifer Whitley, Marta Checchi, Shannon Bounar and Jeff Fisher. The work was supported by NIH HD46501 and RR00165, and NIMH Training Fellowship T32-MH073525 (VM). This work was also supported in part by the Center for Behavioral Neuroscience and the STC program of the National Science Foundation under agreement No. IBN-9876754. Assays were conducted at the YNPRC Biomarkers Core Facility. The YNPRC is fully accredited by the Association for Assessment and Accreditation of Laboratory Animal Care, International.

\section{References}

1. Richard D, Lin Q, Timofeeva E. Eur J Pharmacol 2002;440:189-97. [PubMed: 12007535]

2. Bartolomucci A, Pederzani T, Sacerdote P, Panerai AE, Parmigiani S, Palanza P. Psychoneuroendocrinology 2004;29:899-910. [PubMed: 15177705]

3. Jarrell H, Hoffman JB, Kaplan JR, Berga S, Kinkead B, Wilson ME. Physiol Behav 2008;93:80719. [PubMed: 18190935]

4. Meerlo P, Overkamp GJ, Koolhaas JM. Psychoneuroendocrinology 1997;22:155-68. [PubMed: 9203226]

5. Sachser N, Lick C. Physiol Behav 1989;46:137-44. [PubMed: 2574889]

6. Pecoraro N, Reyes F, Gomez F, Bhargava A, Dallman MF. Endocrinology 2004;145:3754-3762. [PubMed: 15142987]

7. Teegarden SL, Bale TL. Physiol Behav 2008;93:713-23. [PubMed: 18155095]

8. Adam TC, Epel ES. Physiol Behav 2007;91:449-58. [PubMed: 17543357]

9. Dallman MF, Pecoraro N, Akana SF, La Fleur SE, Gomez F, Houshyar H, Bell ME, Bhatnagar S, Laugero KD, Manalo S. Proc Natl Acad Sci U S A 2003;100:11696-701. [PubMed: 12975524]

10. Smagin GN, Howell LA, Redmann S Jr, Ryan DH, Harris RB. Am J Physiol 1999;276:R1461-8. [PubMed: 10233040]

11. Warne JP. Mol Cell Endocrinol 2009;300:137-46. [PubMed: 18984030]

12. Krahn DD, Gosnell BA, Levine AS, Morley JE. Brain Res 1988;443:63-9. [PubMed: 2834018]

13. Kas MJ, Bruijnzeel AW, Haanstra JR, Wiegant VM, Adan RA. J Mol Endocrinol 2005;35:159-64. [PubMed: 16087729]

14. Kuo LE, Kitlinska JB, Tilan JU, Li L, Baker SB, Johnson MD, Lee EW, Burnett MS, Fricke ST, Kvetnansky R, Herzog H, Zukowska Z. Nat Med. 2007

15. Mastorakos G, Zapanti E. Nutr Neurosci 2004;7:271-80. [PubMed: 15682923]

16. Stengel A, Goebel M, Million M, Stenzel-Poore MP, Kobelt P, Monnikes H, Tache Y, Wang L. Endocrinology 2009;150:153-60. [PubMed: 18787020]

17. Kojima M, Hosoda H, Date Y, Nakazato M, Matsuo H, Kangawa K. Nature 1999;402:656-60. [PubMed: 10604470]

18. Faulconbridge LF, Grill HJ, Kaplan JM. Diabetes 2005;54:1985-93. [PubMed: 15983198]

19. Bernstein IS. J Theor Biol 1976;60:459-72. [PubMed: 822241] 
20. Sapolsky RM. Science 2005;308:648-52. [PubMed: 15860617]

21. Kaplan JR, Adams MR, Clarkson TB, Koritnik DR. Atherosclerosis 1984;53:283-95. [PubMed: 6543317]

22. Shively CA, Grant KA, Ehrenkaufer RL, Mach RH, Nader MA. Ann N Y Acad Sci 1997;807:5747. [PubMed: 9071402]

23. Wilson ME, Fisher J, Fischer A, Lee V, Harris RB, Bartness TJ. Physiol Behav 2008;94:586-94. [PubMed: 18486158]

24. Cohen S. Ann N Y Acad Sci 1999;896:246-53. [PubMed: 10681901]

25. Wilson ME, Fisher J, Fischer A, Lee V, Harris RB, Bartness TJ. Physiology \& Behavior 2008;94:586-594. [PubMed: 18486158]

26. Wilson ME, Pazol K, Legendre A, Fisher J, Chikazawa K. Endocrine 2005;26

27. Paiardini M, Hoffman J, Cervasi B, Ortiz AM, Stroud F, Silvestri G, Wilson ME. Brain Behav Immun 2009;23:286-93. [PubMed: 18992804]

28. Shively CA, Laber-Laird K, Anton RF. Biological Psychiatry 1997;41:871-82. [PubMed: 9099414]

29. Shively CA. Biological Psychiatry 1998;44:882-91. [PubMed: 9807643]

30. Kaplan JR, Adams MR, Clarkson TB, Manuck SB, Shively CA, Williams JK. Psychosomatic Medicine 1996;58:598-611. [PubMed: 8948008]

31. Morgan D, Grant KA, Gage HD, Mach RH, Kaplan JR, Prioleau O, Nader SH, Buchheimer N, Ehrenkaufer RL, Nader MA. Nat Neurosci 2002;5:169-74. [PubMed: 11802171]

32. Grant KA, Shively CA, Nader MA, Ehrenkaufer RL, Line SW, Morton TE, Gage HD, Mach RH. Synapse 1998;29:80-3. [PubMed: 9552177]

33. Shively CA, Friedman DP, Gage HD, Bounds MC, Brown-Proctor C, Blair JB, Henderson JA, Smith MA, Buchheimer N. Arch Gen Psychiatry 2006;63:396-403. [PubMed: 16585468]

34. Michopoulos V, Berga SL, Kaplan JR, Wilson ME. Biol Reprod 2009;81:1154-63. [PubMed: 19605783]

35. Gust DA, Gordon TP, Wilson ME, Ahmed-Ansari A, Brodie AR, McClure HM. Brain Behav Immun 1991;5:296-307. [PubMed: 1954404]

36. Shively CA, Register TC, Friedman DP, Morgan TM, Thompson J, Lanier T. Biol Psychol 2005;69:67-84. [PubMed: 15740826]

37. Troisi A. Stress 2002;5:47-54. [PubMed: 12171766]

38. Broadbear JH, Winger G, Rivier JE, Rice KC, Woods JH. Neuropsychopharmacology 2004;29:1112-21. [PubMed: 14997174]

39. Vulliemoz NR, Xiao E, Xia-Zhang L, Rivier J, Ferin M. Endocrinology 2008;149:869-74. [PubMed: 18063681]

40. Graves FC, Wallen K. Horm Behav 2006;49:233-6. [PubMed: 16055125]

41. Walker ML, Gordon TP, Wilson ME. J Med Primatol 1982;11:291-302. [PubMed: 6153017]

42. Blank MS, Gordon TP, Wilson ME. Acta Endocrinol (Copenh) 1983;102:190-5. [PubMed: 6829259]

43. Choi DC, Furay AR, Evanson NK, Ulrich-Lai YM, Nguyen MM, Ostrander MM, Herman JP. Psychoneuroendocrinology 2008;33:659-69. [PubMed: 18378095]

44. Kim H, Whang WW, Kim HT, Pyun KH, Cho SY, Hahm DH, Lee HJ, Shim I. Brain Res 2003;983:201-8. [PubMed: 12914981]

45. Barry D, Pietrzak RH, Petry NM. Ann Epidemiol 2008;18:458-66. [PubMed: 18329894]

46. Heiskanen TH, Niskanen LK, Hintikka JJ, Koivumaa-Honkanen HT, Honkalampi KM, Haatainen KM, Viinamaki HT. J Clin Psychiatry 2006;67:1422-7. [PubMed: 17017829]

47. Zellner DA, Loaiza S, Gonzalez Z, Pita J, Morales J, Pecora D, Wolf A. Physiol Behav 2006;87:789-93. [PubMed: 16519909]

48. Nagaya N, Kojima M, Uematsu M, Yamagishi M, Hosoda H, Oya H, Hayashi Y, Kangawa K. Am J Physiol Regul Integr Comp Physiol 2001;280:R1483-7. [PubMed: 11294772]

49. Neary NM, Small CJ, Wren AM, Lee JL, Druce MR, Palmieri C, Frost GS, Ghatei MA, Coombes RC, Bloom SR. J Clin Endocrinol Metab 2004;89:2832-6. [PubMed: 15181065] 
50. Akamizu T, Takaya K, Irako T, Hosoda H, Teramukai S, Matsuyama A, Tada H, Miura K, Shimizu A, Fukushima M, Yokode M, Tanaka K, Kangawa K. Eur J Endocrinol 2004;150:44755. [PubMed: 15080773]

51. Druce MR, Wren AM, Park AJ, Milton JE, Patterson M, Frost G, Ghatei MA, Small C, Bloom SR. Int J Obes (Lond) 2005;29:1130-6. [PubMed: 15917842]

52. Kamegai J, Tamura H, Shimizu T, Ishii S, Sugihara H, Wakabayashi I. Endocrinology 2000;141:4797-800. [PubMed: 11108296]

53. Wren AM, Small CJ, Ward HL, Murphy KG, Dakin CL, Taheri S, Kennedy AR, Roberts GH, Morgan DG, Ghatei MA, Bloom SR. Endocrinology 2000;141:4325-8. [PubMed: 11089570]

54. Shimbara T, Mondal MS, Kawagoe T, Toshinai K, Koda S, Yamaguchi H, Date Y, Nakazato M. Neurosci Lett 2004;369:75-9. [PubMed: 15380311]

55. Abizaid A, Liu ZW, Andrews ZB, Shanabrough M, Borok E, Elsworth JD, Roth RH, Sleeman MW, Picciotto MR, Tschop MH, Gao XB, Horvath TL. J Clin Invest 2006;116:3229-39. [PubMed: 17060947]

56. Kelley AE, Baldo BA, Pratt WE, Will MJ. Physiol Behav 2005;86:773-95. [PubMed: 16289609]

57. Vulliemoz NR, Xiao E, Xia-Zhang L, Wardlaw SL, Ferin M. Endocrinology 2005;146:784-9. [PubMed: 15514083]

58. Dimitrov EL, DeJoseph MR, Brownfield MS, Urban JH. Endocrinology 2007;148:3666-73. [PubMed: 17463058]

59. Gust DA, Gordon TP, Hambright MK, Wilson ME. Horm Behav 1993;27:318-31. [PubMed: 8225256]

60. Stavisky RC, Adams MR, Watson SL, Kaplan JR. Hormones \& Behavior 2001;39:232-8. [PubMed: 11300714]

61. Czoty PW, Gould RW, Nader MA. J Neuroendocrinol 2009;21:68-76. [PubMed: 19094095]

62. Wilson ME, Fisher J, Brown J. Physiology \& Behavior 2005;84:449-458. [PubMed: 15763583]

63. DeVries AC, Glasper ER, Detillion CE. Physiol Behav 2003;79:399-407. [PubMed: 12954434]

64. Doyle LA, Baker KC, Cox LD. Am J Primatol 2008;70:542-50. [PubMed: 18189243]

65. Barbosa MN, Mota MT. Primates 2009;50:253-60. [PubMed: 19277829]

66. Odendaal JS, Meintjes RA. Vet J 2003;165:296-301. [PubMed: 12672376]

67. Knutson B, Cole S, Wolkowitz O, Reus V, Chan T, Moore E. Ann N Y Acad Sci 1997;807:492-3. [PubMed: 9071379]

68. Mehlman PT, Higley JD, Faucher I, Lilly AA, Taub DM, Vickers J, Suomi SJ, Linnoila M.

American Journal of Psychiatry 1995;152:907-13. [PubMed: 7538731]

69. Aguilera G. Trends Endocrinol Metab 1998;9:329-36. [PubMed: 18406298]

70. Amaral DG. Biol Psychiatry 2002;51:11-7. [PubMed: 11801227]

71. Holsboer F. J Affect Disord 2001;62:77-91. [PubMed: 11172875]

72. Berga SL, Mortola JF, Girton L, Suh B, Laughlin G, Pham P, Yen SS. J Clin Endocrinol Metab 1989;68:301-8. [PubMed: 2493024] 


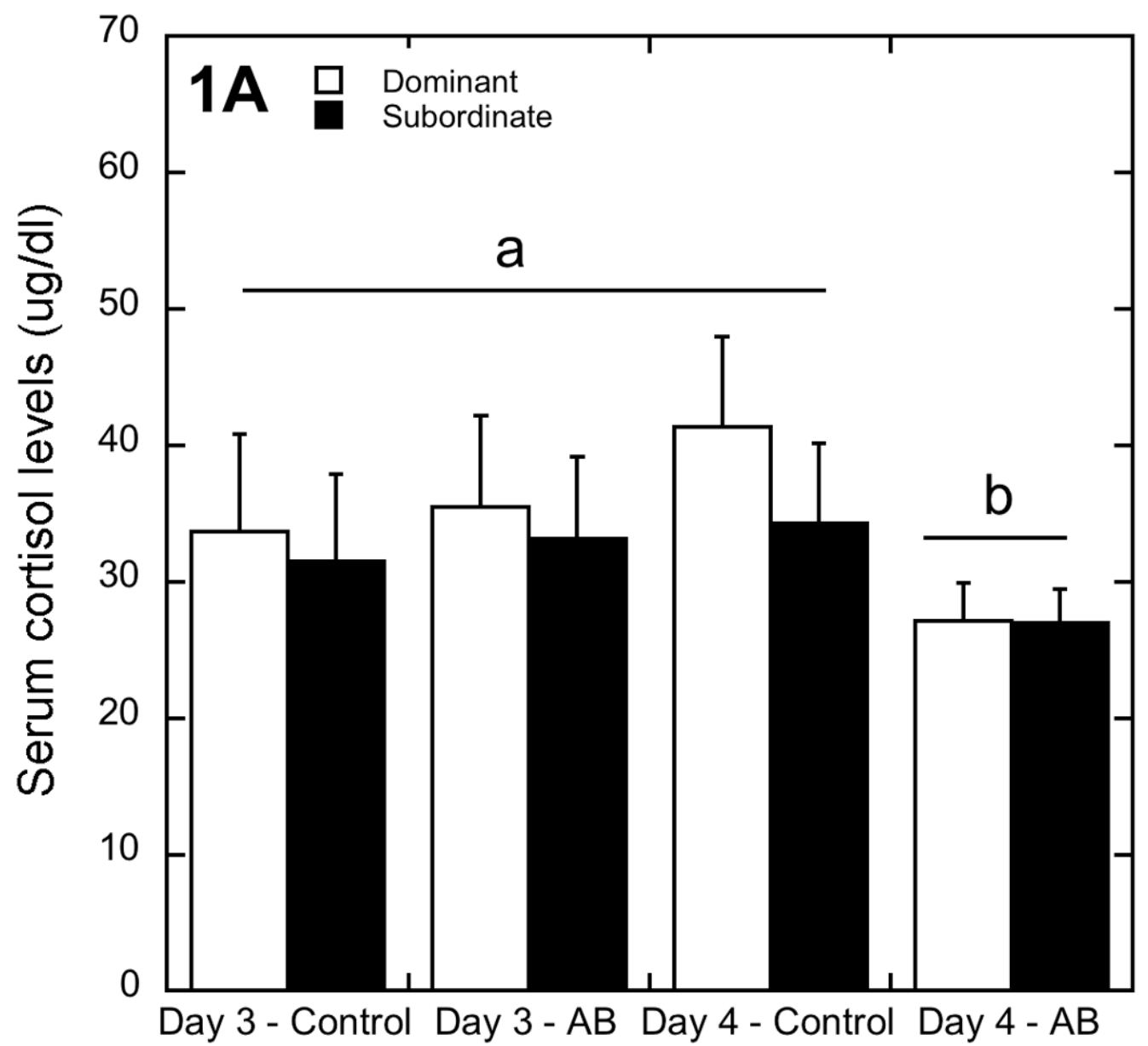

Figure 1.

Peripheral cortisol levels (mean \pm SEM) for dominant and subordinate animals at the conclusion of each of the two treatment phases. Astressin B decreased peripheral cortisol levels in both dominant and subordinate animals by day four of astressin B treatment (marked by letters). 


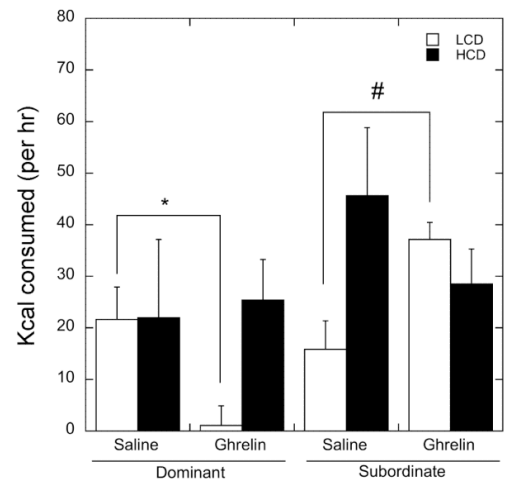

Figure 2.

Mean \pm SEM of kcal consumed of LCD (open bar) and HCD (closed bar) following saline or ghrelin IV injection in dominant and subordinate animals over four hours. Ghrelin administration decreased LCD consumption in dominant animals (depicted by *).

Conversely, ghrelin increased LCD consumption in subordinate animals (marked by \#).

There was no main effect of ghrelin, and it did not interact significantly with either status or astressin B administration. 


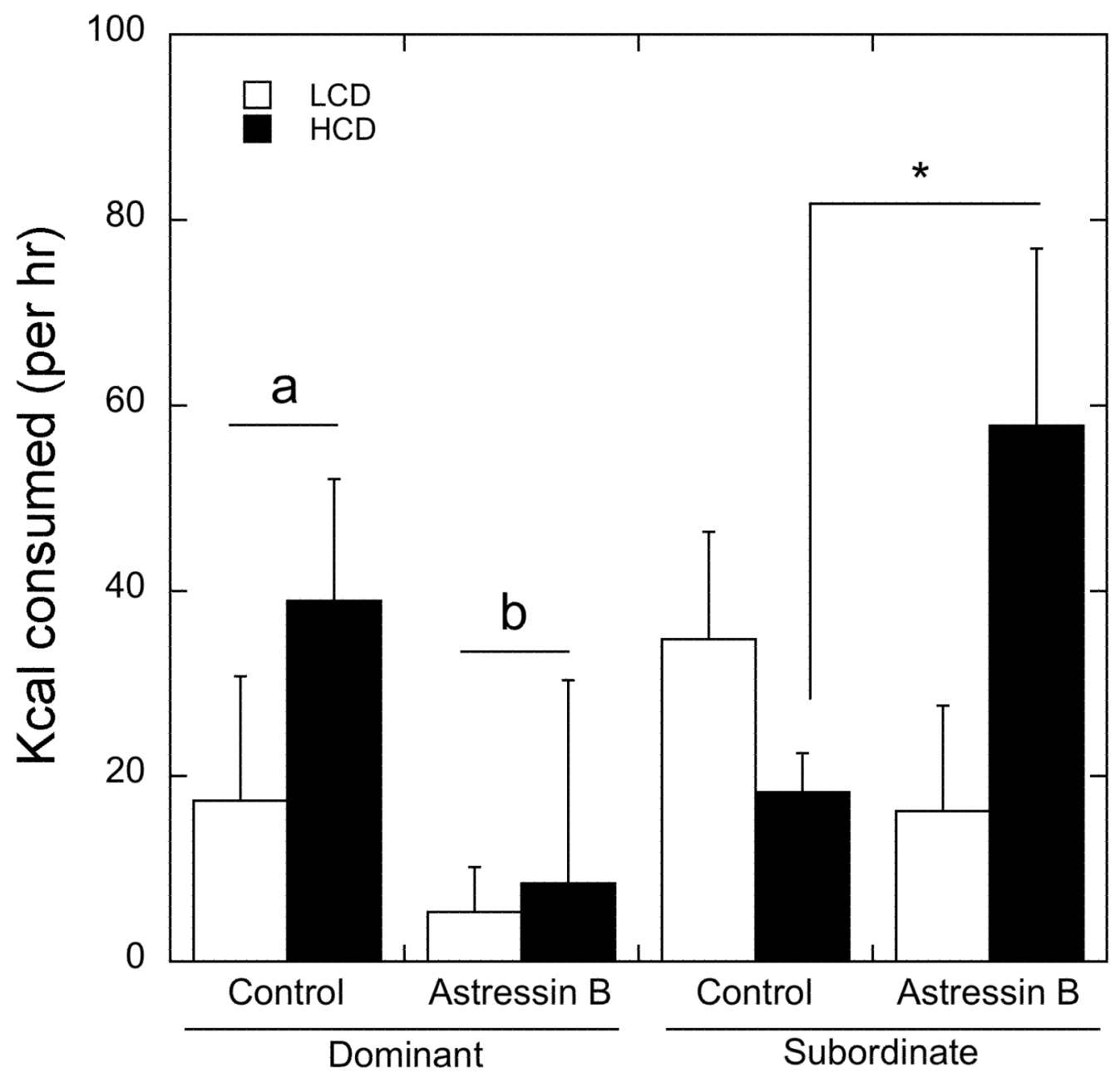

Figure 3.

Mean \pm SEM of kcal consumed of LCD (open bar) and HCD (closed bar) following saline or astressin B injection in dominant and subordinate animals over four hours. Astressin B administration decreased total intake in dominant animals (depicted by letters). Astressin B increased HCD ingestion in subordinate animals (depicted by *). There was no main effect of astressin B, and it did not interact significantly with either status or ghrelin administration. 

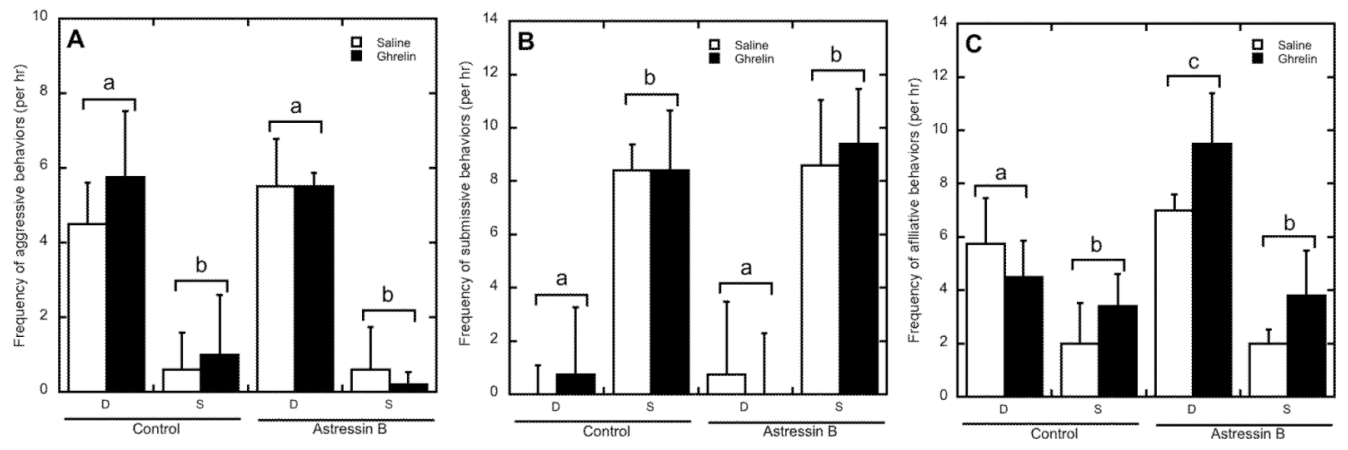

Figure 4.

Mean \pm SEM of the frequency of aggressive (A), submissive (B), and affiliative (C) behaviors per hr following saline (open bar) or ghrelin (closed bar) administration in dominant (D) and subordinate (S) animals during control or astressin B treatments. Dominant animals showed higher rates aggressive behavior in comparison to subordinate animals (A), and subordinate animals showed increased submissive behavior in comparison to dominant animals (B). Dominant animals showed increased affiliative behavior in comparison to subordinate animals, and astressin B increased affiliation only in dominant animals $(C)$. Different letters indicate groups differed significantly $(\mathrm{p}<0.05)$. 
$\stackrel{1}{\circ}$

$\stackrel{\Xi}{\Xi}$

焉

专

芌

先

芷

吾

芯 ฮี

क क

苂

芩导

节

ฮี

.

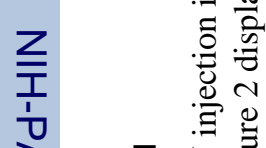

๘

을

$\ddot{\circ}$

竞焉

.

흥

它言

宅氧

ใิ

의

范

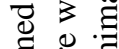

范

要要

ठ․

ฮี

항

䆓

证

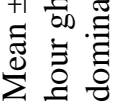

\begin{tabular}{|c|c|c|c|c|c|c|c|c|c|c|}
\hline 节 & & 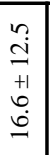 & $\begin{array}{l}\text { ते } \\
\alpha \\
+1 \\
n \\
2 \\
2\end{array}$ & 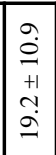 & $\left|\begin{array}{l}0 \\
\infty \\
\infty \\
+1 \\
\infty \\
\delta \\
i\end{array}\right|$ & & $\begin{array}{l}2 \\
2 \\
2 \\
+1 \\
n \\
2 \\
\text { nे }\end{array}$ & $\mid \begin{array}{l}0 \\
0 \\
n \\
+1 \\
0 \\
0 \\
0 \\
0\end{array}$ & $\begin{array}{l}0 \\
0 \\
\infty \\
\infty \\
+1 \\
0 \\
0 \\
0\end{array}$ & \begin{tabular}{|l}
\multirow{2}{f}{} \\
+ \\
+1 \\
+ \\
$\infty$ \\
$\infty$ \\
$\infty$
\end{tabular} \\
\hline 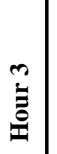 & & 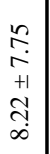 & $\begin{array}{c}0 \\
i \\
n \\
+1 \\
+\infty \\
0\end{array}$ & $\begin{array}{l}0 \\
\hat{0} \\
0 \\
+1 \\
0 \\
0 \\
0\end{array}$ & $\begin{array}{c}\tilde{v} \\
\tilde{+} \\
+ \\
+1 \\
b \\
b \\
i\end{array}$ & & 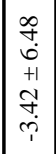 & 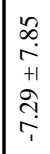 & $\begin{array}{l}\tilde{\sigma} \\
\dot{n} \\
+1 \\
+1 \\
m \\
\\
-1\end{array}$ & 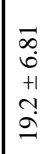 \\
\hline 萻 & & 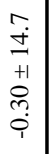 & 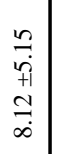 & 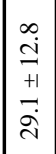 & $\mid \begin{array}{c}f \\
\dot{f} \\
+ \\
+ \\
\stackrel{f}{-} \\
-\end{array}$ & & $\begin{array}{l}0 \\
\propto \\
o \\
+1 \\
0 \\
\infty \\
\sigma \\
\sigma\end{array}$ & 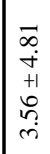 & $\begin{array}{l}\vec{n} \\
\infty \\
+1 \\
0 \\
0 \\
\infty\end{array}$ & 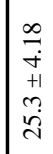 \\
\hline$\overline{\underline{\mathbf{E}}}$ & & $\begin{array}{l}\text { I } \\
\text { İ } \\
+1 \\
\tilde{N} \\
\text { İ }\end{array}$ & $\begin{array}{l}1 \\
0 \\
+1 \\
+1 \\
0 \\
0 \\
\infty\end{array}$ & $\mid \begin{array}{l}0 \\
0 \\
0 \\
+1 \\
\infty \\
\infty \\
\end{array}$ & $\left|\begin{array}{c}0 \\
0 \\
0 \\
+1 \\
\\
\dot{+} \\
+ \\
\dot{+}\end{array}\right|$ & & $\begin{array}{l}\tilde{f} \\
\tilde{r} \\
+1 \\
+1 \\
6 \\
\dot{n}\end{array}$ & $\begin{array}{l}\hat{\sigma} \\
\dot{+} \\
+1 \\
\alpha \\
\sigma \\
\dot{1}\end{array}$ & $\begin{array}{l}\tilde{c} \\
\dot{r} \\
+1 \\
+ \\
\tilde{f} \\
\dot{r}\end{array}$ & 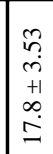 \\
\hline & & 己ิ & 己્తి & 己્રિ & Оి & & 己ે & 己્తి & 恿 & త్రి \\
\hline & 套 & 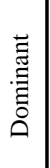 & & 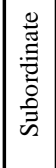 & & 旅 & 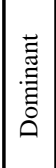 & & 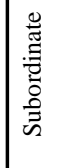 & \\
\hline
\end{tabular}

Endocrine. Author manuscript; available in PMC 2011 October 1. 